\title{
Justifications of Intellectual Property Rights: A Discussion on Locke and Hegel's Theories
}

Muhamad Helmi Muhamad Khair ${ }^{1}$, Haswira Nor Mohamad Hashim²

${ }^{1}$ Faculty of Law, Universiti Teknologi MARA, Malaysia

muham8041@uitm.edu.my

2 Faculty of Law, Universiti Teknologi MARA, Malaysia

haswira648@uitm.edu.my

\section{Abstract}

Introduction to The Problem: At its core, Locke's main argument is centralised in the role of labour, while Hegel's principal idea lies in one's will, self-actualisation as well as personal expression. As both thinkers posit strong arguments in substantiating their views, discussions surrounding this topic may influence one to favour a particular theory over the other.

Purpose/Objective Study: This paper makes a modest attempt to discuss the justifications of intellectual property rights by focusing on two well-known philosophers, John Locke and G.W.F Hegel.

Design/Methodology/Approach: The research design is exploratory as this paper aspires to explore the basis for the grant of intellectual property rights from the lenses of both theories. Therefore, the research methodology is purely doctrinal and theoretical. The research approach is mainly based on library research, focusing on a reading and analysis of Locke and Hegel's published works, as well as other materials such as journal articles, commentaries, and textbooks.

Findings: This article contributes to the existing body of knowledge by highlighting that neither Locke nor Hegel could provide one-fit-for-all justifications of intellectual property rights. Nevertheless, it is worth stating that both philosophers do contribute thoughtful insights that reflect important values worthy of considerations and should never be undermined when framing policies and laws on intellectual property rights. Paper Type: General Review

Keywords: John Locke; Labour Theory, G.W.F Hegel, Personality Theory, Intellectual Property

\section{Introduction}

Intellectual properties (IP) are creations of minds such as literary and artistic works (protected under copyright law), inventions (protected under patent law), symbols, logos, and names used in commerce (protected under trademark law) (WIPO, 2004). Besides, the term "intellectual property rights (IPRs)" refers to certain exclusive rights which are granted to owners to do certain acts of prohibiting others from such actions, and allow the owners to benefit from their investment in their creations (Aplin \& Davis, 2013). 
Concerning IPRs, many theories are discussed by legislators, policymakers, and practitioners to justify the same. It is also observed that John Locke's labour theory and Hegel's personality theory are prominent. However, an investigation into this subject reveals that some quarters may favour one theory over the other. It eventually begs the question of fairness of such a treatment. Therefore, this paper aspires to revisit discussions on both views and analyse their strengths and weaknesses in justifying the IPRs. Before proceeding with the discussions, the next part will first explain the methodology that this paper adopts to undertake the study.

\section{Methodology}

The research design is exploratory as this paper aspires to explore the basis for the grant of IPRs from the lenses of both theories. Therefore, the research methodology is purely doctrinal and theoretical. The research strategy is mainly based on library research, focusing on a reading of Locke and Hegel's published works, as well as other materials such as journal articles, commentaries, and textbooks. From the relevant literature, this article analyses the theories to extract patterns of their strengths and shortfalls. These points are then assessed against the IPRs backdrop to explore the viability of the theories' arguments in providing the basis for justifications. The following section will describe the background of both ideas, starting with John Locke's labour theory.

\section{Results and Discussion}

\section{John Locke's Labour Theory}

This section begins with a review of both theories, which aims at providing a background of the same. One of the most influential theories in the discussion of IPRs justifications is derived from John Locke's seminal work entitled "Second Treaties of Government (1690)." Theologically founded, he asserted that persons own themselves and their labour, and God had given the world to humans in common. When a person works or utilises things from the commonly owned Earth, the outcome would become his property. John Locke's theory that justifies private property as natural right (also known as Natural Right theory) was extracted from this excerpt "The labour of his body and the work of his hands, we may say are properly his. Whatsoever then, he removed out of the states that nature has provided with and left it in, he hath mixed his labour with it and joined to it something that is his own and thereby makes it his property" (Locke, 1690/1988).

Applying his theory to the IP domain, whenever a person mixes his labour with something from the commons (such as ideas, views, or raw material), the output will become his personal property because every person has an inalienable right to his intellectual labour. Hettinger (1989) further states that intellectual creations would not exist but for a person's perseverance, intelligence, and effort, thus entitling him to the fruits of his labour. Resonating Hettinger's view, Moore (2001) and Himma (2008) describe that the process of creating new works may be expensive and can be 
unpleasant, laborious, and exhilarating - which further warrants the grant of IPRs. Therefore, states have the responsibility to protect the owner's rights over their intellectual property by giving them the right to control how their work is to be exploited (Fisher, 2001). For example, if one writes a novel from a specific religious belief, creates Youtube contents for online viewers, invents a particular type of spoon for Parkinson's patients to feed themselves, or designs a logo to represent his business. Such a novel, Youtube video, invention, and trademark would be protected by their respective laws under the IP as the owners invested their labour and time in creating them.

The embodiment of Locke's labour theory can be seen in Article 5(2) of the Berne Convention, i.e., the no-formality principle in copyright law (Lu, 2013). As a matter of one's natural right, copyright protection should automatically exist upon the date of creation, and no formality (such as registration or notification) is required to be fulfilled before the grant of copyright protection. A similar labour-theory based justification can also be seen in the patent law context. New inventions need a party to expend labour in appropriating ideas and other sources from the common property given by God. By mixing labour with these ideas, such a party produces new invention which can be beneficial to the public and, as a result, should obtain property rights over the same (Tay, 2013; Machlup and Penrose, 1950; Lim, 2003).

It should be noted that the Lockean labour theory is not absolute because it comes with two provisos (limitations). These provisos are essential due to the continuous encroachment of technology over intangible matters (Dutfield \& Suthersanen, 2008; Zemer, 2006):

\section{The Enough and as Good Proviso}

This proviso posits that an appropriation of a property will be considered valid and legitimate if there is enough and good is left in common for others. Nozick (1974), in his analysis, suggests that such acquisition of property should not cause harm to other persons (such as harm of the public being left poorer). In light of this, the grant of a patent right to an inventor is justified because the public is not harmed; instead, they benefit from the said invention (Nozick, 1974). Hence, the term of patent protection should also not last long because it would hinder other persons to produce other innovations and devices independently from the same knowledge. The purpose of this proviso has been summarised by Wendy Gordon (1993) that the creator should have a property in their original works. It only provided that such a grant of property does not harm other persons' equal abilities to create or to draw upon the pre-existing cultural matrix and scientific. In light of copyright law, for instance, a creator of work shall not hold permanent protection over his work. Once the copyright term lapses, any persons should be allowed to create derivative works without having obtained permission from the original author, and this would contribute to the growing body of literature and further allow a continuous flow of creative works in the market. 


\section{The No Waste Proviso}

Locke stressed that a labourer must not waste his or her property or take more than he or she can use, which is derived from Locke's word "nothing was made by God for man to spoil or destroy." This proviso ensures substantial equality by limiting the size of holdings to the amount a person can work directly. John Hughes (1988) impliedly regarded this proviso as unnecessary by saying that many intellectual property systems neither embody nor require the no-waste conditions as ideas are not perishable. Countering Hughes, Donald Richards (2002) opined otherwise. For example, in patent law, the no-waste proviso ensures that the appropriation of new ideas via patents ought not to involve waste. In this regard, Donald Richards (2002) argued that there were a lot of cases where new ideas and innovations had been delayed or permanently lost by interests who used patents to prolong their existing intellectual and physical capital stick. Appropriated images can also be wasted if they are not fully utilised. Essentially, the application of no-waste proviso to IPRs will require owners to have enough recourses to exploit their ideas and to ensure sufficient access to the intellectual creations embodying their ideas.

\section{Public Domain and Labour Theory}

Chander and Sunder (2004) define 'public domain' as "the resources for which legal rights to access and use are for free are held broadly," - which Dusollier (2011) viewed it as an open content space with materials that be exploited by anybody. In this particular context, Locke's theory has also developed a pivotal influence on the "public domain" discussion. As aforementioned, this theory requires proper management and configuration of IPRs, and this is crucial in avoiding being inflicted on others, particularly by the uncontrollable acquisition of property and the wasteful depletion of the common. For this reason, Lockean labour theory is a robust mechanism in promoting and maintaining a healthy public domain, a view that many belief stimulates the formation of novel ideas, creation of new works, and evolution of authors (Dutfield \& Suthersanen, 2008). In the next part, this paper will continue with the second theory in justifying the IPRs, Hegel's personality theory.

\section{G.W.F Hegel's Personality Theory}

Another theoretical writing that attracted more significant attention to IPRs justification comes from Hegel's influential paper "Philosophy of Right (1820)". Commonly regarded as a powerful alternative to Locke's justification by most scholars, Hegel posits that property provides a unique mechanism for selfactualisation, for personal expression, and dignity and recognition as a person (Hegel, 1820/2005).

The backbone of Hegel's theory lies in the notion of "the will as the core of an individual's existence." Each person has both internal existence (will) and external existence (sphere of freedom). He believed that the sphere of freedom is achieved by putting one's choice into external objects. Without actualising the will, an individual 
does not gain the capacity to concretise (Koutras, 2019; Dutfield \& Suthersanen, 2008).

Therefore, it can be seen that Hegel's personality theory focuses more on the relationship between property and personality. The theory asserts that personal expression is an instrument of self-actualisation that gives moral rights in the intellectual creations to the creator, and such outcomes are considered "extension of his or her personality. As such, property right should be justified as it is essential to the development of one's personality (Radin, 1982). An example of the embodiment of Hegel's personality theory can be seen in Article 6bis of the Berne Convention, i.e., the so-called moral rights in copyright law (Yoo, 2019). A further example can also be seen in Section 25(2) of Malaysia's Copyright Act 1987, which embodies the author's moral right on integrity and reputation. Indonesia has similar protections as well, as enshrined in Section 24 (right of integrity) and Section 33 (right of paternity) of Law No.28 of 2014 on Copyright. As a whole, an author's work is regarded as an extension of his personality; the moral rights principally preserve the author's integrity and reputation in his work (Khaw \& Tay, 2017), which precisely echoes Hegel's personality theory.

Like Locke, Hegel also allows for the public domain. In paragraph 69 of his work, "The result is that they may regard as their own property the capital asset accruing from their learning and may claim for themselves the right to reproduce their leaning in books of their own." It is argued that third parties may utilise the ideas since their mode of expression will produce some unique form of their work, which can be further reproduced, i.e., creating derivative works from the public domain.

Following Hegel's justification, it is also worth noting the following guidelines concerning the proper shape of the intellectual property system, which is formed by Justin Hughes (1988):

1. We should be more willing to grant protection to the products of highly expressive intellectual activities (such as novels) than the works of less expressing academic activities (such as genetic research).

2. Because of a person's persona (including his physical features, mannerisms, and history) is a big receptacle for personality, it deserves ample legal protection, even though ordinarily it does not result from labour.

3. Authors and inventors should be permitted to earn respect, honour, admiration, and money from the public by selling or giving away copies of their works. Still, they should not be permitted to surrender their right to prevent others from mutilating or misattributing their works.

\section{Analysis of Labour Theory}

Locke's theory may be influential to some quarters, but it is not without criticisms. The first account relates to the role of labour. Hume (1978) and Waldrom (1983) argue that the role of labour in justifying one's right is still unclear because the notion 
of mixing action with an object is rather preposterous. In contrast, Mossoff (2012), Russel (2004), and Simmons (1998) countered by stating that the idea of "mixing labour" was just a metaphor to illustrate activities that a person engages in creating something meaningful in his life - like transforming wheat into bread, and timber into houses. In this regard, this paper intends to agree with the latter's argument as such analogy also reflects the activities and essential sources (e.g., research, budgets, and time) engaged in the IP domain.

Besides, it is impossible to search for intellectual creations that exist from nothing as most of them, especially copyright-protected works, are influenced by previous existing works and authors (Dutfield \& Suthersanen, 2008). Even if some inventions can be independently created, Penrose (1953) questioned the rationale of giving a patent right to the first inventor and deprive the second inventor based on the natural-labour basis. Just because the later parties are unlucky to be second in time, that alone is not a strong reason to stop him of his right as both parties have invested their time and labour in producing the inventions. Therefore, expanding from the above views, this article criticises the labour theory for being too vague and, to some extent - selective, as it does not provide a clear guideline on the grant of right in this instance. In other words, while it may be plausible to confer the IPRs for the labour that is poured into the creation of products, it is also quite incoherent to conclude that the value of intellectual creation is entirely attributable to the labour of an individual. It is because scholarly results may and may not be created from something.

Besides, under Locke's labour theory, it seems that almost everyone (such as individuals, corporations, performers) can be given IPRs, and indeed, many industries would fervently support this theory as it would work to their advantage (Dutfield \& Suthersanen, 2008; Zemer, 2006). This premise is also questionable. While it may be practical to confer the IPRs in a simple straight forward work project where one may quickly identify the relevant contributor, the application of the said theory seems problematic when it involves multiple parties with complex distributions of efforts labours. For instance, the development of a complicated piece of software. Locke's labour theory does not guide as to how this jointly held property might function in this instance. In another perspective, the application of Locke's labour theory may be quite unfair as it tends to grant the IPRs to products that are created from a simple project and exclude others into the state of ambiguity.

Most intellectual creations in this modern era are the results of processes of labour that are distributed across time, investors, organisations, and industries. This chain of relationships may involve the uneven distribution of labour, skills, and investment. Logically speaking, significant parties would need to have more of a claim to a property right than the contributors of lesser significance. Nonetheless, Locke's labour theory does not guide in this area as well. In this regard, Aplin and Davis (2013) argued that it is unclear why 'labour' should entitle an entity to ownership over the whole work when a person's labour only adds a small value to intellectual creation. 
Another problem with the Lockean labour theory is that labour is an imprecise mechanism for designating intangible property boundaries. Aplin and Davis (2013) quoted an example of an author who has developed a detailed love story. It tells the typical plot of two lovers whose love is prevented because of their different backgrounds - in this scenario, are we to conclude that the author should own every aspect of the story? Concerning this point, another concern arises as to how the property's boundary is to be determined by using the Lockean labour theory. If one works over a few square feet of land, he will have the right over that piece of land, and not the entire land. However, in other circumstances, the Labour theory seems to be unworkable. Nozick (1974) was doubtful with this proposition when he asked, "If I own a can of tomato juice and spill it in the sea so that its molecules mingle evenly throughout the sea, do I thereby come to own the sea, or have I foolishly dissipated my tomato juice?"

Further, John Locke also mentioned that God had given the Earth to humankind in common, and the humanity may find limited resources of subject matter (such as land and water), and resources with unlimited capacity (such as ideas). In this regard, Arnold Plant, citing David Hume's seminal work 'Enquiry Concerning Principles of Morals,' states that property right becomes significant when the objects are scarce. Still, the right becomes purposeless when there are plenty (Plant, 1934). In this present discourse, there is no scarcity in infinite resources such as intellectual property, which can be consumed and utilised without the supply being exhausted. As such, it is argued that the Lockean theory is relevant to the subject matter of 'finite capacity' but not in instances of 'infinite resources' such as intellectual property (Dutfield \& Suthersanen, 2008; Zemer, 2006). Hence, this paper observes that it is easy to analyse and conceptualise subject matters such as land and water as there are potentially usable by anyone and everyone. Still, when it comes to abstract objects and concepts such as ideas, it isn't easy to visualise, such as being owned in common.

\section{Analysis of Personality Theory}

If the difficulty with Locke's Theory arises from the questionable role of one's labour, Hegel's justification stems from the definition of 'personality' itself. The term 'personality' embodies a 'pattern of thinking' or 'reputation." However, Michael Spence (2002) posits that it is different from 'reputation' - instead, the term means 'self-presentation' (including self-expression). Following Hegel's thought on that matter, it can be said that one may agree on the nature of "personality," but it is argued in doubt as to whether 'personality' can be distinguished in the creator's works.

Many theorists contended that the application of Hegel's theory could be seen effectively in literary and artistic works. For example, Justin Hughes eloquently put it, "Some works are better suited to display a creator's personality" - such as novels, poems, and fine art - as these are receptacles for personality (Hughes, 1988). Justin Hughes (1988) further stated that works such as inventions, microchips, and computer software are vaguely displaying "personality traits" as these works usually 
embody utilitarian solutions to particular needs, not the personality of the inventor. Here are examples to illustrate Hughe's concern:

1. Songs are produced by composers and musicians to meet the market needs and consumer's growing interests - and not only to portray or ingrain their personality in the products.

2. Thomas Edison, when he invented the light bulb, searched for the filament material that would burn the longest, not a filament that reflects his personality.

3. Guglielmo Marconi, in the wireless field, chose a particular wavelength for his radio because it could travel much farther than waves slightly longer, not because of a preference of self-expression.

4. Melitta Bentz, an inventor of the coffee filter, experimented with various means but ended up using blotting paper from school exercise books, at it gave cleanfinished brew. Here, it is impossible to conclude her effort with coffee-filter as 'embodying her personality.'

Besides, Justin Hughes has also pointed out one fundamental difficulty with this theory. As explained above, in Locke's labour theory, some intellectual creations have no apparent social value or require no labour to produce, leaving these pieces of property unjustified by the labour theory. Hegel's personality theory encounters the same problem as well, especially with intellectual creations that reflect little or no personality from their creators. Justin Hughes (1988) stated that "Personality is manifested to varying degrees in different objects." In light of his argument, one may find difficulty in determining which intellectual creations embody more personality than others - which leads to a question of varying degrees of protection - should more character imply more protections? What if it involves an intellectual creation emerges from a joint-authorship and artistry - the same difficulty faced by Locke's labour theory, which remains unanswered.

\section{Conclusion}

This article has provided a brief background and debates on two critical theories in justifying the IPRs. In sum, Locke's main argument is centralised in the role of labour, while Hegel focuses on one's will, self-actualisation as well as personal expression. Based on the above discussions, it is observed that both Locke and Hegel provided strong arguments for their idea. Upon careful examination of their thoughts, some quarters may incline to favor one theory over the other by fervently highlighting the shortfalls of the theories. Such a practice must be celebrated with caution to induce good progress of knowledge in this area. However, one fact that could not be discredited is that neither Locke nor Hegel could provide a comprehensive justification for IPRs. Put it more simply; they are not superior to one another as both theories have their strengths and weaknesses. Be that as it may, this paper believes that the discussions on this aspect will continue to grow, and it is worth stating that both thinkers do contribute thoughtful theories to understand the grant of IPRs better. Depending on which ideas one chooses to justify the IPRs, both Locke and 
Hegel could provide a reasonable basis to substantiate the creator's IPRs and eventually secure their beneficial interests.

\section{References}

Aplin, T., \& Davis, J. (2013). Intellectual Property Law: Text, Cases, and Materials (Second ed.). Oxford, United Kingdom: Oxford University Press.

Chander, A., \& Sunder, M. (2004). The Romance of the Public Domain. California Law Review, 92(5), 1331-1371.

Dusollier, S. (2011). (Re)introducing Formalities in Copyright as a Strategy for the Public Domain. In L. Guibault \& C. Angelopoulos (Eds.), Open Content Licensing: From Theory to Practice. Amsterdam, Netherlands: Amsterdam University Press

Dutfield, G., \& Suthersanen, U. (2008). Global Intellectual Property Law. United Kingdom: Edward Elgar Publishing Limited.

Fisher, W. (2001). Theories of Intellectual Property. In S. Munzer (Ed.), New Essays in the Legal and Political Theory of Property. Cambridge, United Kingdom: Cambridge University Press.

Gordon, W. J. (1993). A Property Right in Self-Expression: Equality and Individualism in the Natural Law of Intellectual Property. The Yale Law Journal, 102(7), 15331609.

Hegel, G.W.F (2005). Philosophy of Right (S. W. Dyde, Trans.). New York, US: Dover Publications Inc. (Original work published 1820)

Hettinger, E. C. (1989). Justifying Intellectual Property. Philosophy and Public Affairs, 18(1), 31-52.

Himma, K. E. (2008). The Justification of Intellectual Property: Contemporary Philosophical Disputes. Journal of the American Society for Information Science and Technology, 59(7), 1143-1161.

Hughes, J. (1988). The Philosophy of Intellectual Property. Georgetown LJ 287, 77(II), 296-314.

Hume, D. (1978 [1739-40]). A Treatise of Human Nature (Second ed.). Oxford: Clarendon Press

Koutras, N. (2019). From Property Right to Copyright: A Conceptual Approach and Justifications for the Emergence of Open Access. Erasmus Law Review, 12(2), 139-154.

Khaw, LT \& Tay, P.S. (2017). Khaw on Copyright Law in Malaysia (Fourth ed.). Singapore: Lexis Nexis.

Lim, W. (2003). Towards Developing a Natural Law Jurisprudence in the US Patent System. Santa Clara Computer \& High Technology Law Journal, 19(2), 561-625.

Locke, J. (1988). Two Treatises of Government (P. Laslett, Ed.). Cambridge University Press. (Original work published 1690)

$\mathrm{Lu}, \mathrm{B}$. (2013). The Orphan Works Copyright Issue: Suggestions for International Response. Journal of the Copyright Society of the USA, 60, 255-284.

Machlup, F., \& Penrose, E. (1950). The Patent Controversy in the Nineteenth Century. The Journal of Economic History, 10(1), 1-29.

Moore, A. D. (2017). Intellectual Property and Information Control: Philosophic Foundations and Contemporary Issues. Routledge.

Mossoff, A. (2012). Saving Locke From Marx: The Labour Theory of Value in Intellectual Property Theory. Social Philosophy and Policy, 29(2), 283-317. 
Nozick, R. (1974). Anarchy, State, And Utopia. New York, USA: Basic Books.

World Intellectual Property Organisation (2004). Intellectual Property Handbook. Geneva, Switzerland: WIPO.

Plant, A. (1934). The Economic Theory Concerning Patents for Inventions. Economica, 1(1), 30-51.

Radin, M. J. (1982). Property and Personhood. Stanford Law Review, 34(5), 957-1015.

Richards, D. G. (2002). The Ideology of Intellectual Property Rights in the International Economy. Review of Social Economy, 60(4), 521-541.

Russel, D. (2004). Locke on Land and Labour. Philosophical Studies, 117(1-2), 303325.

Simmons, A. J. (1998). Makers' Rights. The Journal of Ethics, 2(3), 197-218.

Spence, M. (2002). Justifying Copyright. In D. McClean \& K. Schubert (Eds.), Dear Images: Art, Copyright, and Culture. Ridinghouse.

Tay, P.S (2013). Intellectual Property Law In Malaysia. Selangor, Malaysia: Thomson Reuters Malaysia Sdn Bhd.

Yoo, C. S. (2019). Rethinking Copyright and Personhood. University of Illinois Law Review(3), 1039-1078.

Zemer, L. (2006). The Making of A New Copyright Lockean. Harvard Journal of Law \& Public Policy, 29(3), 891-947. 